\title{
The top five qualities of a good friend
}

\section{Alice Allen}

1. They take a genuine interest in you.

What's on your mind?

What's happening?

Already a member?

Forgot your password?

2. They encourage you to be all you can be.

Broadcast yourself.

See who you already know.

Find friends.

Edit friends.

3. They're a giver, not a taker.

Over 7573.660914 megabytes (and counting).

Today we launched the Open Compute Project, an industry-wide initiative for more efficient and economical data centres.

Now you know how to greet people in Hungarian!

4. They're open, honest and real.

We are keenly aware of the trust you place in us and our responsibility to protect your privacy.

You can share your information with friends, friends of friends or everyone, and we offer presets to help you do that.

5. They don't keep you waiting.

Refresh. 